\title{
Stereotactic Ablative Radiotherapy Combined with Immune Checkpoint Inhibitors Reboots the Immune Response Assisted by Immunotherapy in Metastatic Lung Cancer: A Systematic Review
}

\author{
Rodolfo Chicas-Sett ${ }^{1, *} \mathbb{C D}^{\text {, Ignacio Morales-Orue }}{ }^{1}{ }^{\mathbb{D}}$, Juan Castilla-Martinez ${ }^{1}$, \\ Juan Zafra-Martin ${ }^{1}\left(\mathbb{D}\right.$, Andrea Kannemann ${ }^{1}$, Jesus Blanco ${ }^{1}$, Marta Lloret ${ }^{1,2}$ and Pedro C Lara ${ }^{3,4}$ \\ 1 Department of Radiation Oncology, “Dr. Negrín” University Hospital of Gran Canaria, Barranco de la \\ Ballena s/n, 35010 Las Palmas de Gran Canaria, Spain; ignaciomorue@gmail.com (I.M.-O.); \\ juanfe4206@hotmail.com (J.C.-M.); jzafra08@gmail.com (J.Z.-M.); andreakannemann@hotmail.com (A.K.); \\ blancosuar@hotmail.com (J.B.); mllosae@hotmail.com (M.L.) \\ 2 Clinical Oncology, Medical School, Las Palmas University of Gran Canaria, \\ 35001 Las Palmas de Gran Canaria, Spain \\ 3 Department of Oncology, San Roque University Hospital, Calle Dolores de la Rocha 5, \\ 35001 Las Palmas de Gran Canaria, Spain; pedrocarlos.lara@ulpgc.es \\ 4 Faculty of Health Sciences, Fernando Pessoa Canarias University, Calle la Juventud S/N, \\ 35450 Las Palmas, Spain \\ * Correspondence: rchicas@ufm.edu
}

Received: 2 April 2019; Accepted: 24 April 2019; Published: 2 May 2019

check for updates

\begin{abstract}
Background: Immune checkpoint inhibitors (ICI) have represented a revolution in the treatment of non-small-cell lung cancer (NSCLC). To improve these results, combined approaches are being tested. The addition of stereotactic ablative radiotherapy (SABR) to ICI seems promising. A systematic review was performed in order to assess the safety and efficacy of SABR-ICI combination. Material and Methods: MEDLINE databases from 2009 to March 3, 2019 were reviewed to obtain English language studies reporting clinical outcomes of the combination of ICI-SABR in NSCLC. 18 out of the 429 initial results fulfilled the inclusion criteria and were selected for review. Results: Eighteen articles, including six prospective studies, describing 1736 patients treated with an ICI-SABR combination fulfilled the selection criteria. The reported mean rates for local control and distant/abscopal response rates were $71 \%$ and $41 \%$, respectively. Eleven studies reported progression-free survival and overall survival, with a mean of 4.6 and 12.4 months, respectively. Toxicity rates were consistent with the ones attributable to ICI treatment alone. Conclusions: The ICI-SABR combination has a good safety profile and achieves high rates of local control and greater chances of obtaining abscopal responses than SABR alone, with a relevant impact on PFS. More studies are needed to improve patient selection for an optimal benefit from this approach.
\end{abstract}

Keywords: abscopal effect; radiotherapy; immunotherapy; CTLA-4; Anti-PD-1/PD-L1; SABR; ICI; SBRT

\section{Introduction}

\subsection{Lung Cancer and $S A B R$}

Lung cancer is the second most frequently diagnosed tumor worldwide and is the leading cause of cancer-related deaths [1]. No significant changes in 5-year survival have been observed in the last three decades $[2,3]$. 
Radiation therapy (RT) has a role in all stages of non-small-cell lung cancer (NSCLC), including definitive therapy in the oligometastatic setting using SABR [4]. SABR is defined as a RT schedule that uses high (i.e., ablative) doses per fraction in one to five fractions with highly conformal techniques [5]. SABR has been established as a standard of care for patients with early-stage NSCLC who are medically inoperable or who refuse surgery [6-10]. These favorable results have been translated to the oligometastatic setting, where SABR has been adopted as standard treatment for patients not eligible for surgery by improving progression free survival (PFS) and overall survival (OS) [11-24]. Gomez et al. [24] reported a high median PFS of 11.9 months after local consolidative radiotherapy (including SABR) in patients with oligometastatic NSCLC involving $\leq 3$ sites that had not progressed after first line chemotherapy.

\subsection{The Use of Immune Checkpoint Inhibitors (ICI) in Lung Cancer}

NSCLC has traditionally been considered a poorly immunogenic tumor $[25,26]$. Recent advances in the field of immunotherapy, targeting down-regulators of the immune system with different therapeutic agents generically known as immune checkpoint inhibitors (ICI), have shown promising results and are currently establishing a new standard of care in advanced NSCLC [27,28]. The two most therapeutically relevant checkpoints are cytotoxic T-lymphocyte-associated antigen 4 (CTLA-4) and programmed cell death protein-1 (PD-1). Monoclonal antibodies targeting these checkpoints include nivolumab, pembrolizumab (anti-PD-1), atezolizumab, durvalumab (anti-PD-L1) and ipilimumab (anti-CTLA-4). Their goal is to induce immune cell proliferation and activation against cancer cells by "taking off the brakes" of the immune system [29].

The effectiveness of nivolumab in NSCLC was confirmed by two large phase III trials, CheckMate 017 [27] and CheckMate 057 [28], leading to its approval as second-line treatment in advanced NSCLC in October 2015. However, these favorable results for nivolumab monotherapy as second-line treatment were not translated to first-line setting. The CheckMate-026 trial compared nivolumab to standard-of-care chemotherapy in first-line treatment of advanced or recurrent NSCLC with PD-L1 positivity $\geq 5 \%$ and did not demonstrate a significant survival benefit for nivolumab [30].

The efficacy of pembrolizumab was confirmed by the results of the phase II/III trial KEYNOTE-010, which enrolled patients with previously treated advanced NSCLC and PD-L1 expression on at least 1\% of tumor cells and compared OS and PFS for three treatment arms: pembrolizumab (two arms, 2 or $10 \mathrm{mg} / \mathrm{kg}$ ) or docetaxel (one arm, $75 \mathrm{mg} / \mathrm{m}^{2}$ ). In the total population, both pembrolizumab arms had significantly improved OS compared with the docetaxel arm. Among the subgroup of patients with PD-L1 expression PS $\geq 50 \%$, either dose of pembrolizumab significantly improved OS in comparison to docetaxel. Despite these differences in OS, no difference was found in PFS between the three study arms. Pembrolizumab was better tolerated than docetaxel, with grade $\geq 3$ adverse events in $13 \%-16 \%$ vs. $35 \%$ of patients [31].

Atezolizumab was assessed in POPLAR, a phase II trial, comparing atezolizumab with docetaxel in patients with previously treated advanced NSCLC, stratifying patients according to PD-L1 status, histologic type and previous lines of therapy. In the intention-to-treat population, atezolizumab significantly improved median OS compared with docetaxel. PD-L1 expression on tumor cells or tumor-infiltrating immune cells was associated with an OS benefit [32].

Ipilimumab, a CTLA-4 antagonist used in monotherapy in advanced NSCLC, had previously shown limited activity [33]. However, results are promising when combined with cytotoxic chemotherapy. A phase II trial comparing carboplatin/paclitaxel with or without ipilimumab as first-line treatment for patients with advanced NSCLC showed that the addition of ipilimumab significantly improved PFS [34].

Even though these drugs have shown remarkable action against several types of tumors, only $20 \%$ of patients obtain a clinical benefit [35]. Consequently, it is extremely important to study additional treatment alternatives intended to improve response rates. 


\subsection{Rationale of Radiotherapy and ICI Combination}

RT has shown an immunomodulating effect, instigating a localized stimulation of the immune system by increasing antigen presentation (auto-vaccination) through immunogenic cell death (ICD) [36], reducing myeloid-derived suppressor cells (MDSCs) [37], modifying macrophage polarization [37], increasing PD-1 tumor expression and stimulating vascular modification [38], all of which have the potential to modify the tumor microenvironment $[39,40]$. This facilitates a reinvigoration of the immune response, increasing the chances of achieving an abscopal effect; a term coined by Mole in 1953 describing an event in which focalized RT unleashes systemic anti-tumoral action that can result in distant responses [41].

This elusive effect begets new challenges with the widespread use of ICI, encouraging investigators to explore novel therapeutic approaches such as, a) adjusting radiation doses to take full advantage of the potential for immune stimulation, $b$ ) defining the most advantageous sequencing for radiation, c) determining the ideal drugs to use alongside radiation, and d) counteracting the immunosuppressive components concerned [42].

Available data suggests that the combination of RT and ICI may be a feasible and safe strategy, with reports of up to $26.5 \%$ increased abscopal responses and an 8 -month increase in overall survival in melanoma patients treated with this association [42].

\section{Materials and Methods}

\subsection{Search Strategy}

We reviewed MEDLINE (via PubMed) databases from 2009 to March 3, 2019 in order to obtain English language studies reporting clinical outcomes of the combination of RT with ICI in NSCLC. Several terms were used, including "radiotherapy", "immunotherapy", "lung cancer", "SABR", "SRS", "SBRT", "immune checkpoint inhibitors", "anti-CTLA-4", "anti-PD-1", "anti-PD-L1", "abscopal effect". Non-original articles were excluded.

\subsection{Selection of Studies and Data Compilation}

All articles were assessed based on title and abstract. The included studies relevant for this review met the following criteria:

a) Combined RT and sequential or concurrent ICI treatment.

b) External beam RT.

c) Study type included prospective or retrospective.

d) Studies published in English.

\subsection{Statistical Considerations}

Outcomes were analyzed in terms of local control, distant/abscopal response rates, PFS, OS and Toxicity $>$ Grade 3. To analyze distant/abscopal response rates, PFS, OS and toxicity, we pooled the results of each article and calculated a weighted mean (WM) between them. The criteria used were randomization (randomized studies were more highly weighted than non-randomized ones and than other categories), study design (prospective studies were more highly weighted than retrospective studies, which were classified in weight as $n>30$ or $n<30$, respectively) and sample size. The weighted mean was defined by the following formula [43]:

$$
\mathrm{VM}=\sum_{\mathrm{i}=1}^{n_{1}} \mathrm{w}_{\mathrm{i}} \mathrm{Zi} / \sum_{\mathrm{i}=1}^{n_{\mathrm{i}}} \mathrm{w}_{\mathrm{i}}
$$

where $n$ is the sample size and $\mathrm{w}_{\mathrm{i}}$ is the weighting factor of the $\mathrm{i}^{\text {th }}$ observation $(\mathrm{i}=1 \ldots, n)$. 


\section{Results and Discussion}

Our search generated a total of 429 results. Through a process of screening, 18 publications were selected for the review. Out of the 411 studies excluded for this review, 347 were excluded due to not fulfilling the specific inclusion criteria, 8 because of inadequate publication type, 24 due to incorrect intervention or control, 22 did not include the correct endpoints, and 9 were excluded because of an incorrect study design. Therefore, 18 fulfilled the inclusion criteria and were included in our review. The flowchart detailing the systematic literature search process is shown in Figure 1.

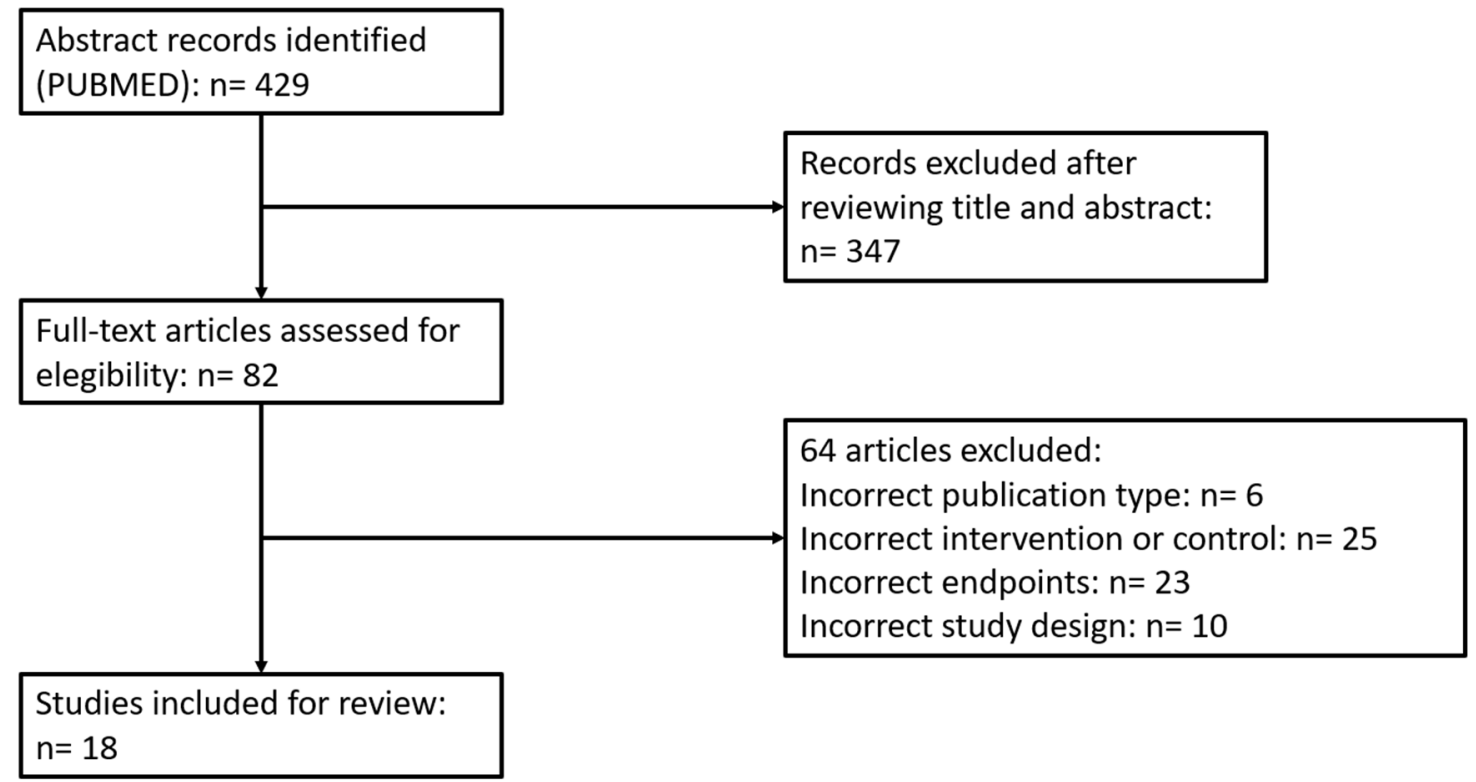

Figure 1. Flow chart of systematic literature search process according to PRISMA statement.

These 18 studies included a total of 1736 patients, and in 6 of them the study design was prospective (Table 1). 
Table 1. Prospective and retrospectives trials reporting clinical results of radiotherapy and ICI combination in metastatic NSCLC.

\begin{tabular}{|c|c|c|c|c|c|c|c|c|c|c|c|c|c|}
\hline Author & Study Type & $\mathrm{N}$ & $\begin{array}{c}\text { Cancer } \\
\text { Histology }\end{array}$ & RT Target & $\begin{array}{c}\text { RT Dose } \\
\text { Gy/Fraction }\end{array}$ & $\begin{array}{l}\text { Treatment } \\
\text { Sequencing }\end{array}$ & IT Agent & IT Dose & $\begin{array}{c}\text { Local Control Rate } \\
\text { (CR+PR+S) } \\
\%\end{array}$ & $\begin{array}{c}\text { Median OS } \\
\text { (months) }\end{array}$ & PFS (months) & $\begin{array}{c}\text { Distant/Abscopal } \\
\text { Response Rate } \\
(\mathrm{CR}+\mathrm{PR}+\mathrm{S}) \%\end{array}$ & $\begin{array}{c}\text { Toxicity } \geq \\
\text { Grade } 3(\%)\end{array}$ \\
\hline $\begin{array}{l}\text { Formenti et al. } \\
2018[44]\end{array}$ & Phase I-II & 39 & NSCLC & NR & $\begin{array}{c}28.5-30 / \\
3-5\end{array}$ & Concurrent & Ipi & $\begin{array}{c}3 \mathrm{mg} / \mathrm{Kg} / \\
3 \mathrm{w}\end{array}$ & NR & 13 & 3.8 & 31\% (Abscopal) & 38 \\
\hline $\begin{array}{c}\text { Theelen et al. } \\
2018 \text { [45] }\end{array}$ & Phase II & 74 & NSCLC & NR & $24 / 3$ & Sequential & Pembro & $200 \mathrm{mg} \mathrm{q} 3 \mathrm{w}$ & NR & NR & 6.4 & $41 \%$ & 17 \\
\hline $\begin{array}{l}\text { Tang et al. } \\
2017 \text { [46] }\end{array}$ & Phase I & $\begin{array}{c}\text { 35 } \\
\text { Lung: } 14\end{array}$ & Various & Lung, liver & $50 / 4$ & $\begin{array}{l}\text { Concurrent } \\
\text { Sequential }\end{array}$ & Ipi & $\begin{array}{c}3 \mathrm{mg} / \mathrm{Kg} / \\
3 \mathrm{w}\end{array}$ & $90 \%$ & 10.2 & 3.2 & $42 \%$ & 34 \\
\hline $\begin{array}{l}\text { Welsh et al. } \\
2017 \text { [47] }\end{array}$ & Phase II & 100 & Various & Lung, liver & $50 / 4$ & $\begin{array}{l}\text { Concurrent } \\
\text { Sequential }\end{array}$ & Ipi & $\begin{array}{c}3 \mathrm{mg} / \mathrm{Kg} / \\
3 \mathrm{w}\end{array}$ & NR & 12 & 5.0 & $67 \%$ & $29 \%$ \\
\hline $\begin{array}{l}\text { Luke et al. } \\
2018 \text { [48] }\end{array}$ & Phase I & $\begin{array}{c}79 \\
\text { Lung: } 7\end{array}$ & Various & $\begin{array}{l}\text { Lung, liver, } \\
\text { bone, } \\
\text { abdomen, } \\
\text { pelvis }\end{array}$ & $\begin{array}{l}30-50 / \\
3-5\end{array}$ & Sequential & Pembro & 200 mg q3w & NR & 9.6 & 3.1 & $\begin{array}{c}26.9 \% \\
\text { (Abscopal) } \\
\text { Systemic: 13\% }\end{array}$ & 10 \\
\hline $\begin{array}{l}\text { Miyamoto et al. } \\
2018[49]\end{array}$ & Prospective & 6 & NSCLC & Lung & $\begin{array}{c}25-48 / \\
3-4\end{array}$ & Sequential & Nivo & $3 \mathrm{mg} / \mathrm{kg} \mathrm{q} 2 \mathrm{w}$ & NR & NR & 4.6 & $50 \%$ & 17 \\
\hline $\begin{array}{l}\text { Mohamad et al. } \\
2018 \text { [50] }\end{array}$ & Retrospective & $\begin{array}{c}59 \\
\text { Lung; } 5\end{array}$ & Various & Extracranial & $\begin{array}{c}>5 \text { Gy perfx/ } \\
1-5\end{array}$ & $\begin{array}{l}\text { Concurrent } \\
\text { Sequential }\end{array}$ & $\begin{array}{l}\text { Nivo, Pembro } \\
\text { Atezo, Ipi }\end{array}$ & NR & NR & Not reached & 6.5 & $26 \%$ & 20 \\
\hline $\begin{array}{l}\text { Lesueur et al. } \\
2018 \text { [51] }\end{array}$ & Retrospective & 104 & NSCLC & $\begin{array}{l}\text { Bone, brain, } \\
\text { lung, others }\end{array}$ & $\begin{array}{l}\text { RT3D: 20-30/ } \\
\text { 5-10 } \\
\text { SABR: 20-36/ } \\
1-6\end{array}$ & $\begin{array}{c}\text { Concurrent }(n=45) \\
\text { Sequential } \\
(n=59)\end{array}$ & Nivo & NR & $2 \mathrm{y}$-LC: $64.4 \%$ & 11.1 & 2.7 & NR & 14.4 \\
\hline $\begin{array}{c}\text { Foster et al. } \\
2019 \text { [52] }\end{array}$ & Retrospective & 228 & NSCLC & Intracranial & $\begin{array}{c}18-50 / \\
1-5\end{array}$ & NR & NR & NR & NR & 18.2 & NR & NR & NR \\
\hline $\begin{array}{l}\text { Shaverdian et al. } \\
2017 \text { [53] }\end{array}$ & Retrospective & 42 & NSCLC & Thoracic & NR & Sequential & Pembro & $\begin{array}{c}2 \mathrm{mg} / \mathrm{kg} \text { or } \\
10 \mathrm{mg} / \mathrm{kg} \mathrm{q} 3 \mathrm{w} ; \\
10 \mathrm{mg} / \mathrm{kg} \mathrm{q} 2 \mathrm{w}\end{array}$ & NR & 11.6 & 4.4 & NR & 13 \\
\hline $\begin{array}{l}\text { Bang et al. } \\
2017 \text { [54] }\end{array}$ & Retrospective & $\begin{array}{c}133 \\
\text { Lung: } 71\end{array}$ & NSCLC & $\begin{array}{l}\text { Lung, bowel, } \\
\text { brain, neck }\end{array}$ & $\begin{array}{c}8-37.5 / \\
1-15\end{array}$ & $\begin{array}{l}\text { Concurrent } \\
\text { Sequential }\end{array}$ & $\begin{array}{c}\text { Anti-CTLA-4 } \\
\text { Anti-PD-1 }\end{array}$ & NR & NR & NR & NR & NR & 9 \\
\hline $\begin{array}{l}\text { Hwang et al. } \\
2017 \text { [55] }\end{array}$ & Retrospective & 164 & $\begin{array}{l}\text { NSCLC } \\
\text { SCLCC }\end{array}$ & Lung & $\begin{array}{l}8-60 / \\
1-30\end{array}$ & $\begin{array}{l}\text { Concurrent } \\
\text { Sequential }\end{array}$ & $\begin{array}{c}\text { Anti-PD-1 } \\
\text { Anti-PD-L1 }\end{array}$ & NR & NR & 12.1 & NR & NR & 13.7 \\
\hline $\begin{array}{l}\text { Hubbelling et al. } \\
2018 \text { [56] }\end{array}$ & Retrospective & 50 & NSCLC & Intracranial & $\begin{array}{l}20-37.5 / 10-15 \\
\text { SRS: } 10-22 / 1\end{array}$ & $\begin{array}{l}\text { Concurrent } \\
\text { Sequential }\end{array}$ & $\begin{array}{l}\text { Nivo; Pembro; } \\
\text { Atezo }\end{array}$ & NR & NR & NR & NR & NR & 9 \\
\hline $\begin{array}{c}\text { Martin et al. } \\
2018 \text { [57] }\end{array}$ & Retrospective & 115 & Various & Intracranial & $\begin{array}{c}25-30 / 5 \\
\text { SRS: } 18-20 / 1\end{array}$ & NR & $\begin{array}{l}\text { Ipi; Nivo; } \\
\text { Pembro }\end{array}$ & NR & NR & NR & NR & NR & NR \\
\hline $\begin{array}{l}\text { Colaco et al. } \\
2016 \text { [58] }\end{array}$ & Retrospective & $\begin{array}{c}\text { 180; } \\
\text { Lung: } 71\end{array}$ & Various & Intracranial & $15-24 / 1$ & Sequential & $\begin{array}{l}\text { Anti CTLA-4; } \\
\text { Anti-PD-1 }\end{array}$ & NR & NR & 9.3 & NR & NR & NR \\
\hline $\begin{array}{l}\text { Chen et al. } \\
2017[59]\end{array}$ & Retrospective & $\begin{array}{c}260 ; \\
\text { Lung } 157\end{array}$ & Various & Intracranial & $\begin{array}{c}15-25 / \\
1-5\end{array}$ & $\begin{array}{l}\text { Concurrent }(n=28) \\
\text { Sequential }(n=51)\end{array}$ & $\begin{array}{l}\text { Anti-CTLA-4 } \\
\text { Anti-PD-1 }\end{array}$ & NR & $\begin{array}{l}\text { Concurrent: 1y-LC: } 88 \% \\
\text { Sequential: } \\
\text { 1y-LC: } 79 \%\end{array}$ & $\begin{array}{c}\text { Concurrent } \\
24.7 \\
\text { Sequential14.5 }\end{array}$ & 2.3 & NR & 16 \\
\hline
\end{tabular}


Table 1. Prospective and retrospectives trials reporting clinical results of radiotherapy and ICI combination in metastatic NSCLC.

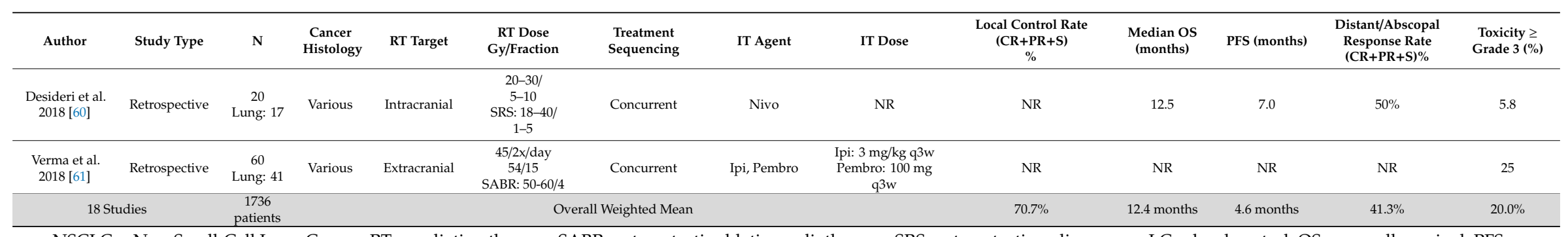

NSCLC = Non-Small-Cell Lung Cancer; RT = radiation therapy; SABR = stereotactic ablative radiotherapy; SRS = stereotactic radiosurgery; LC = local control; OS = overall survival; PFS = progression free survival; IT = immunotherapy; Pembro = pembrolizumab; Nivo = nivolumab; Atezo = atezolizumab; Ipi = ipilimumab; CTLA-4 = cytotoxic T-lymphocyte-associated antigen 4; PD-1 = programmed cell death protein-1; PD-L1 = programmed death-ligand. 


\subsection{Is It Possible to Obtain Target Control with the Combination of RT and ICI?}

Data on local control (LC) was available for only 3 studies (399 patients), 1 being phase I and 2 being retrospective. Overall, the weighted mean LC rate was $70.7 \%$, ranging from $64 \%$ to $90 \%[46,51,59]$.

It must be noted that the intent of SABR-ICI treatment is to change the natural history of the disease by targeting metastatic lesions and, as a secondary objective, to improve locorregional control using lower SABR doses.

At present, SABR is the standard treatment for non-operable NSCLC, with LC rates $\geq 90 \%$ when administering doses $\geq 100$ Gy BED 10 [62]. In this context, high SABR doses combined with ICI have been evaluated by Tang et al. [46] in a phase I trial. 14 patients were treated with SABR doses of 50 Gy in 4 fractions, reporting a similar LC rate (90\%). Conversely, a similar LC rate can be observed with the use of lower SABR doses combined with ICI [51,59], as summarized in Table 1. This situation can be explained by the radio-sensitizing effect of ICI and the immunogenic effects of SABR, such as induction of ICD, release of tumor-associated antigens, alteration of target cell immunophenotype and modulation of the TME [63].

Additionally, an effective LC rate could play a fundamental role in metastatic patients who develop isolated sited progression while on ICI, enabling a sustained and more durable systemic response [64]. For example, Pike et al. [65] reported that the use of radiotherapy in oligoprogression allowed for the continuation of anti-PD-1 treatment, while maintaining a systemic response in 23 of 59 patients.

\subsection{Using RT-ICI Combination to Improve Systemic Immunotherapy Effects: Abscopal Response in NCSLC}

Eight out of the 18 studies included in this review [44-50,60] assessed and reported the systemic response observed. It is important to note that only two studies were specifically designed to evaluate the abscopal response as a primary endpoint in NSCLC [44,48], while the rest of the studies reported abscopal responses as the systemic response rate according to RECIST criteria.

Overall, the distant/abscopal response was reported in a cohort of 412 patients with a weighted mean of $41.3 \%$, ranging from $26.0 \%$ to $67.0 \%$, as described in Table 1 and Figure 2.

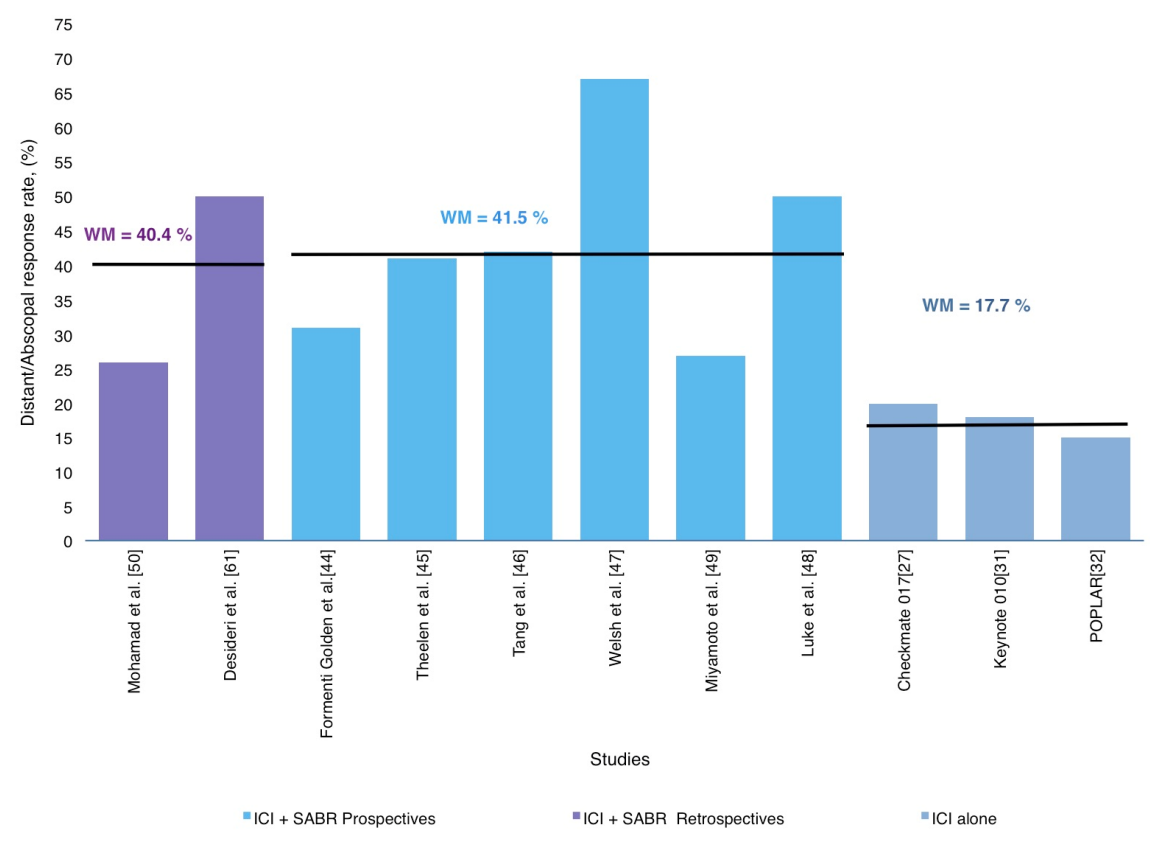

Figure 2. Distribution of weighted mean distant/abscopal response rates according in prospective and retrospective studies in SABR-ICI combination and ICI alone trials.

Similar distant/abscopal responses were found among retrospective and prospective studies $(34.0 \%$ and $42.8 \%$, respectively), but better than studies with ICI alone (15\%-44\%) $[27,28,30-32]$. Figure 2 
represents an approximate distribution of the distant/abscopal response rate reported in all studies included in this review. For instance, the phase II trial by Formenti et al. [44] included patients with chemo-refractory metastatic NSCLC who received ipilimumab concurrently with SABR (30 Gy in 5 fractions) to a single metastatic lesion. Abscopal response was $31 \%$ including CR, PR and SD, whereas the median OS for survivors was 43 months (range: 38-47 months). Luke et al. [48] also reported an abscopal response rate of $26 \%$. As mentioned above, most studies included in this section showed promising outcomes regarding systemic disease control, but their heterogeneity in relation to primary histology and radiotherapy fractionation represents a weak point in the interpretation of their results. To help answer the question of whether SABR and ICI combination increases systemic response in metastatic NSCLC patients, Theelen et al. [45] performed a randomized phase II trial that included 74 patients with advanced NSCLC ( $>2^{\text {nd }}$ Line) which were randomized (1:1) to receive pembrolizumab ( $200 \mathrm{mg}$ q3w) alone or pembrolizumab preceded by SABR $(8 \mathrm{~Gy} \times 3$ fractions within 7 days prior to the first cycle) on a single metastasis. The overall response rate was $19 \%$ in the control arm (pembrolizumab alone) and $41 \%$ in the SABR-pembrolizumab arm. Thus, this trial concluded that SABR-pembrolizumab treatment resulted in a doubling of overall response rate while maintaining a good safety profile.

\subsection{The Abscopal Response Potentially Delays Disease Progression}

PFS data was available in 818 patients included in 11 reviewed trials [44-52,58,59]. The weighted PFS mean was 4.6 months (2.3-7 months), as shown in Figure 3.

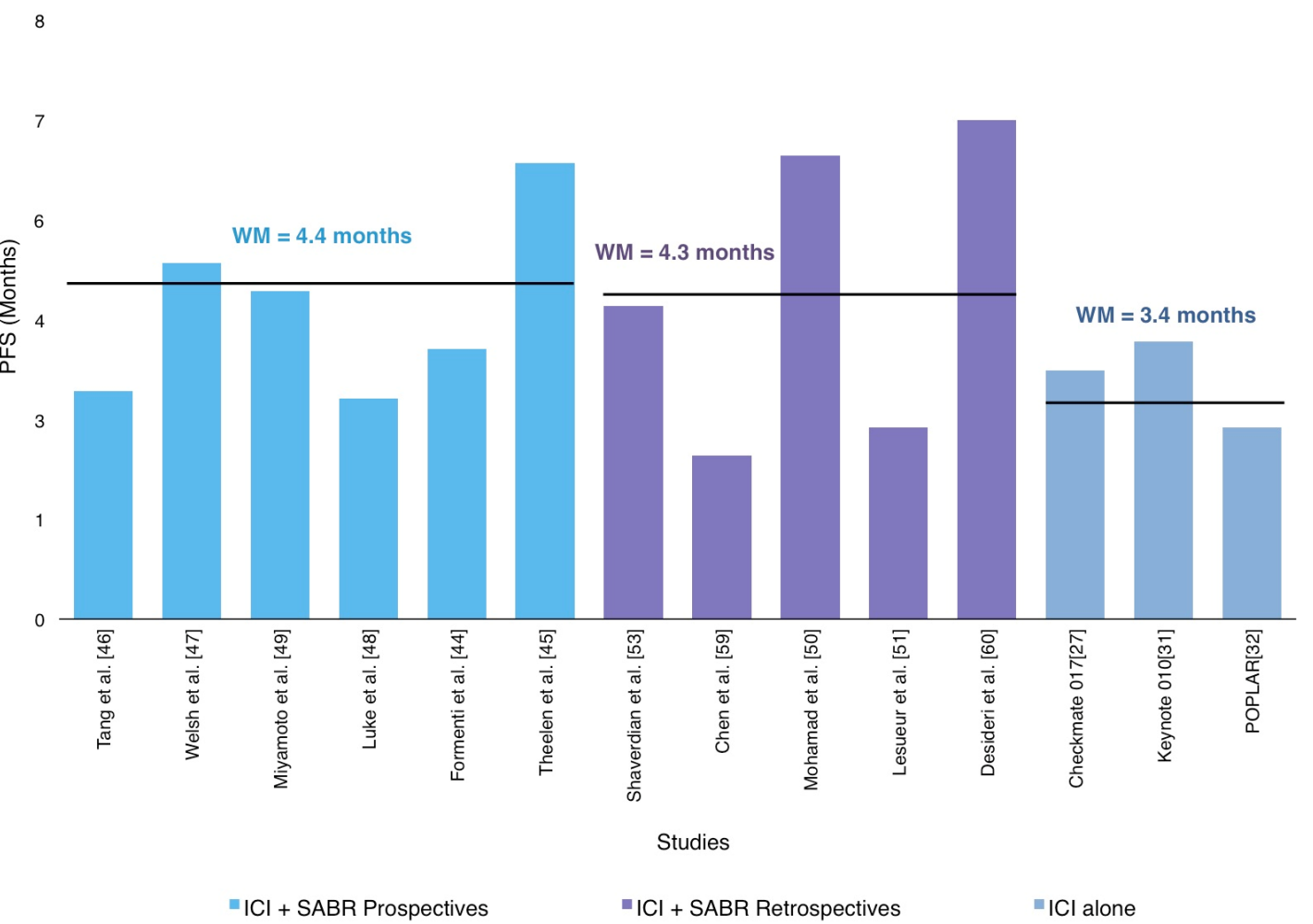

Figure 3. Distribution of weighted mean progression-free survival (PFS) according in prospective and retrospective studies in SABR-ICI combination.

Although the PFS reported in the studies included in this review has a wide variation regardless of the nature of its design (retrospective or prospective), our results were consistent with the major studies that had previously evaluated the use of ICI in monotherapy $[27,28,30-32]$ as described in Figure 3 . On the other hand, prospective trials, have reported higher PFS with the combination of RT and ICI. One of them is a randomized phase II trial that reported an improvement in PFS: 6.4 months in the 
SABR-Pembro arm compared with 1.8 months in the Pembro alone arm [43]. In addition, a secondary analysis of the phase I KEYNOTE-001 trial, with a median follow-up at 32.5 months, showed that $43 \%$ $(n=42)$ of patients who received extracranial irradiation before pembrolizumab reported significantly longer PFS than those without prior RT (4.4 vs 2.1 months; $p=0.01$ ) [52], suggesting the potential of radiotherapy to turn traditional non-responders into responders.

Thus, all of the above suggests that select patients with metastatic NSCLC may be appropriate candidates for this new promising treatment approach.

\subsection{Could Radiotherapy and ICI Combination Improve Overall Survival in Metastatic NSCLC Patients?}

11 out of the 18 articles included in this review [44,46-48,51-53,55,59,60] reported the median OS of the subjects accrued in their respective studies. The weighted OS mean for the 1310 patients was 12.4 months (9.0-24.7 months), as shown in Figure 4.

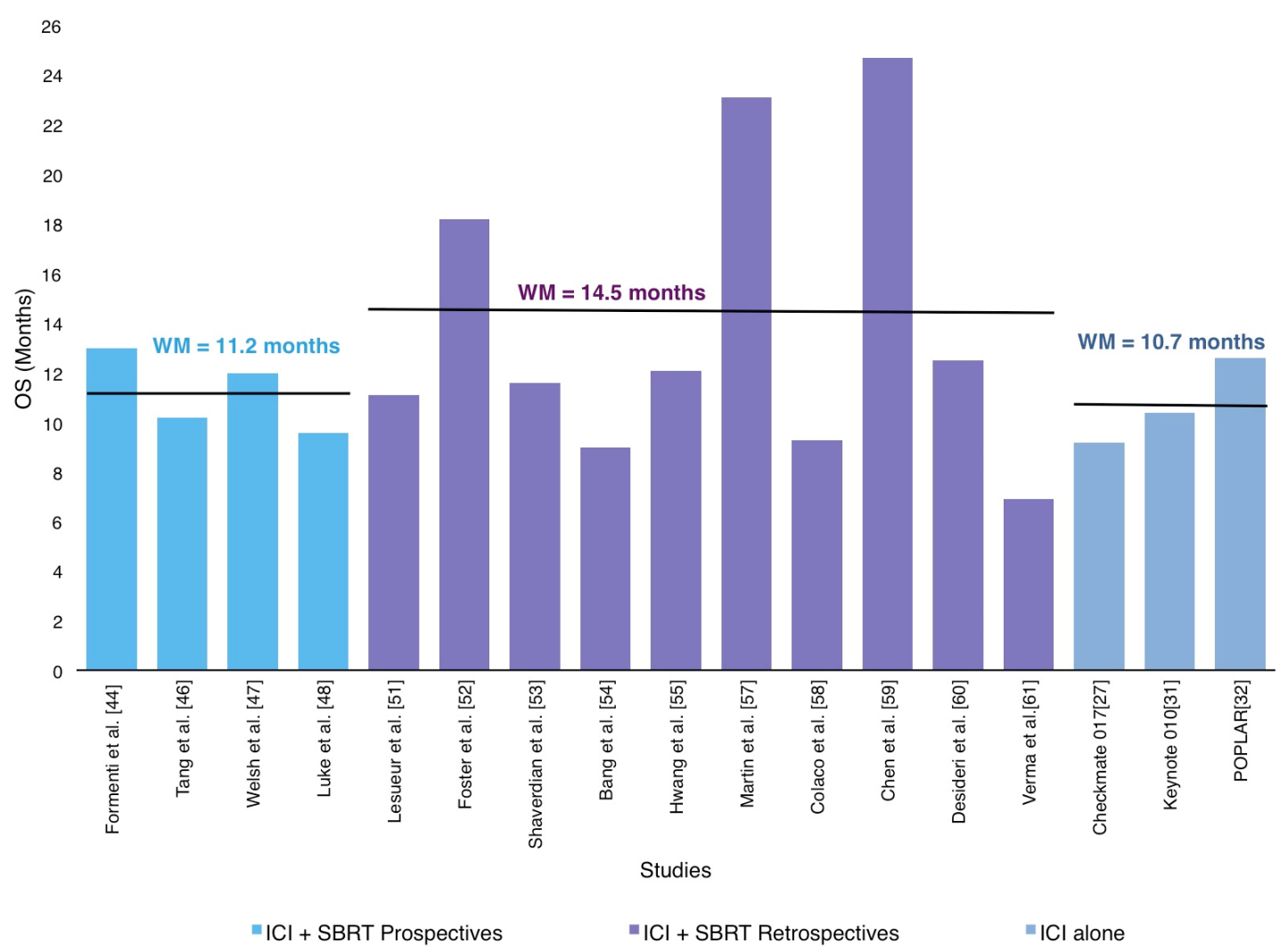

Figure 4. Distribution of weighted mean overall survival (OS) according in prospective and retrospective studies in SABR-ICI combination and ICI alone studies.

A similar benefit with RT-ICI combination was observed in comparison with the reported OS in the phase II and III trials of anti-CTLA-4 and anti-PD-1/PD-L1 without RT [27,28,30-32]. The most relevant studies reporting OS are described below and summarized in Table 1.

Given that the majority of these studies include unselected patients who had been heavily treated beforehand, interpretations on OS findings should be taken with caution. For this reason, an analysis of the main factors related to OS is crucial. Therefore, in this review we have taken into consideration variables such as timing of RT administration, dose and fractionation, irradiation site and tumor burden [51-53,55,58-60].

Regarding the timing of RT treatment, we observed contradictory data. For example, Sharvedian et al. [53], in his retrospective analysis of the results of the phase 1 KEYNOTE-001 trial, found that median OS was higher in patients with prior RT (10.7 months vs 5.3). Hwang et al. [55] performed a retrospective cohort study of 164 patients with metastatic lung cancer treated with 
PD-1/PD-L1 inhibitors, finding a median OS of 12.1 months and reduced all-cause mortality in patients who received RT before ICI initiation. Chen et al. [59] retrospectively evaluated 260 patients (157 with NSCLC) treated with ICI (ipilimumab, nivolumab or pembrolizumab) and concurrent or sequential SRS/SABR $(n=79)$, finding that SRS-SABR with concurrent ICI was associated with improved OS compared with both SRS-SABR alone (24.7 vs 12 . 9 months, $p=0.002$; hazard ratio, 2.69) and non-concurrent SRS-SABR and ICI ( $p=0.006$; hazard ratio, 2.40). On the other hand, Lessuer et al. [50], in a retrospective study of a multicentric analysis on the safety and efficacy of concurrent or sequential ICI and hypofractioned-RT, found that the OS did not seem to be associated with the timing of RT administration.

In regard to RT doses, Foster et al. [52] retrospectively analyzed a national cancer database that included stage IV NSCLC patients receiving chemotherapy or immunotherapy. RT modality was classified as SABR to intra- and/or extracranial sites. Two findings of this study are particularly interesting: 1) median OS was 18.2 months for SRS + ICI compared to 14.3 months for SRS + chemotherapy, and 2) SRS with biologically effective dose (BED) >60 Gy was independently associated with improved OS.

RT location and local control has also been associated with OS in patients with RT-ICI treatments. Colaco et al. [58] included 180 patients (71 with NSCLC) who underwent GammaKnife SRS with sequential chemotherapy, targeted therapy or ICI. Median OS was significantly longer in patients who developed local response (23.7 vs 9.9 months, respectively).

Lastly, Desideri et al. [60] published a retrospective analysis that included 20 patients with metastatic NSCLC $(n=17)$ and RCC who received concomitant nivolumab and RT. Oligoprogressive patients treated with ablative intent, compared to patients undergoing RT with palliative-only intent, had statistically longer OS (17.9 vs 10.3 months, HR 0.41 CI $0.16-1.02, p=0.04)$.

In short, our review shows that a clinical benefit in OS when using RT-ICI combination remains unclear. This could be attributed to the heterogeneity of these studies, as well as the fact that patient follow-up is still limited.

\subsection{Radiotherapy and ICI: A Safe Combination}

Immunotherapy has a different and often better-tolerated profile of adverse effects (AEs) than chemotherapy. Toxicity from ICI usually includes fatigue, rash, myalgias and pneumonitis. Even though these side effects are generally mild, they can also be potentially severe. The evidence available regarding these AEs comes from three main trials: Checkmate 017, Keynote 010 and POPLAR, which found grade $\geq 3$ irAEs of $7 \%, 13 \%-16 \%$ and $11 \%$, respectively when administered in monotherapy $[27,28,30-32]$, as described in Table 2.

Table 2. Summary of Toxicity $\geq$ Grade 3 with RT-ICI combinations in NSCLC.

\begin{tabular}{cccc}
\hline Study Design & $\begin{array}{c}\text { Follow-Up in Months, } \\
\text { Median, Range }\end{array}$ & $\begin{array}{c}\text { Toxicity } \geq \text { Grade } 3 \\
\%, \text { Weighted Median }\end{array}$ & Most Common irAEs \\
\hline AntiPD1/antiPD-L1 + SABR & $\begin{array}{c}14.0 \\
(2,9-33)\end{array}$ & $14,5 \%$ & $\begin{array}{c}\text { Pneumonitis, asthenia, breakthrough pain, } \\
\text { colitis, neurological and hepatic toxicity }\end{array}$ \\
\hline Anti CTLA4 + SABR & $\begin{array}{c}20.0 \\
(2-38)\end{array}$ & $26,0 \%$ & $\begin{array}{c}\text { Pneumonitis, fatigue, liver enzymes } \\
\text { increase, colitis and neurological }\end{array}$ \\
\hline AntiPD1/AntiPD-L1 alone & 11.0 & $10,8 \%$ & $\begin{array}{c}\text { Pneumonia, increased aspartate } \\
\text { aminotransferase, skin reactions, } \\
\text { pneumonitis, neutropenia, anemia, } \\
\text { thrombocytopenia, diarrhea }\end{array}$ \\
\hline
\end{tabular}

IT = immunotherapy; RT = radiotherapy; irAEs = immune-related adverse events.

Evidence on the combination of immunotherapy with radiotherapy is still limited, but the data available suggests that toxicity derived from the combined treatment does not increase in comparison to immunotherapy alone $[27,28,30-32]$ Grade $\geq 3$ toxicity from the RT/ICI combination ranges between $10 \%-17 \%$ for anti PD-1/PD-L1 and $29 \%-38 \%$ for anti CTLA-4, according to the 6 prospective studies that we found (Table 1). These numbers are consistent with the AEs than can be expected from ICI treatment 
alone $[27,28,30-32]$. The only exception is the phase III study by Govindan et al. [66], which describes a grade $\geq 3$ toxicity of $53 \%$. However, this trial included chemotherapy in addition to ipilimumab, which might explain these increased side effects.

It must be noted, however, that few studies randomize patients between ICI monotherapy and ICI plus radiotherapy. Moreover, in the studies where RT is sequential to immunotherapy, basal toxicity from ICI is rarely mentioned [45-49]. Registered toxicity with the combined treatment can be seen in Figure 5.

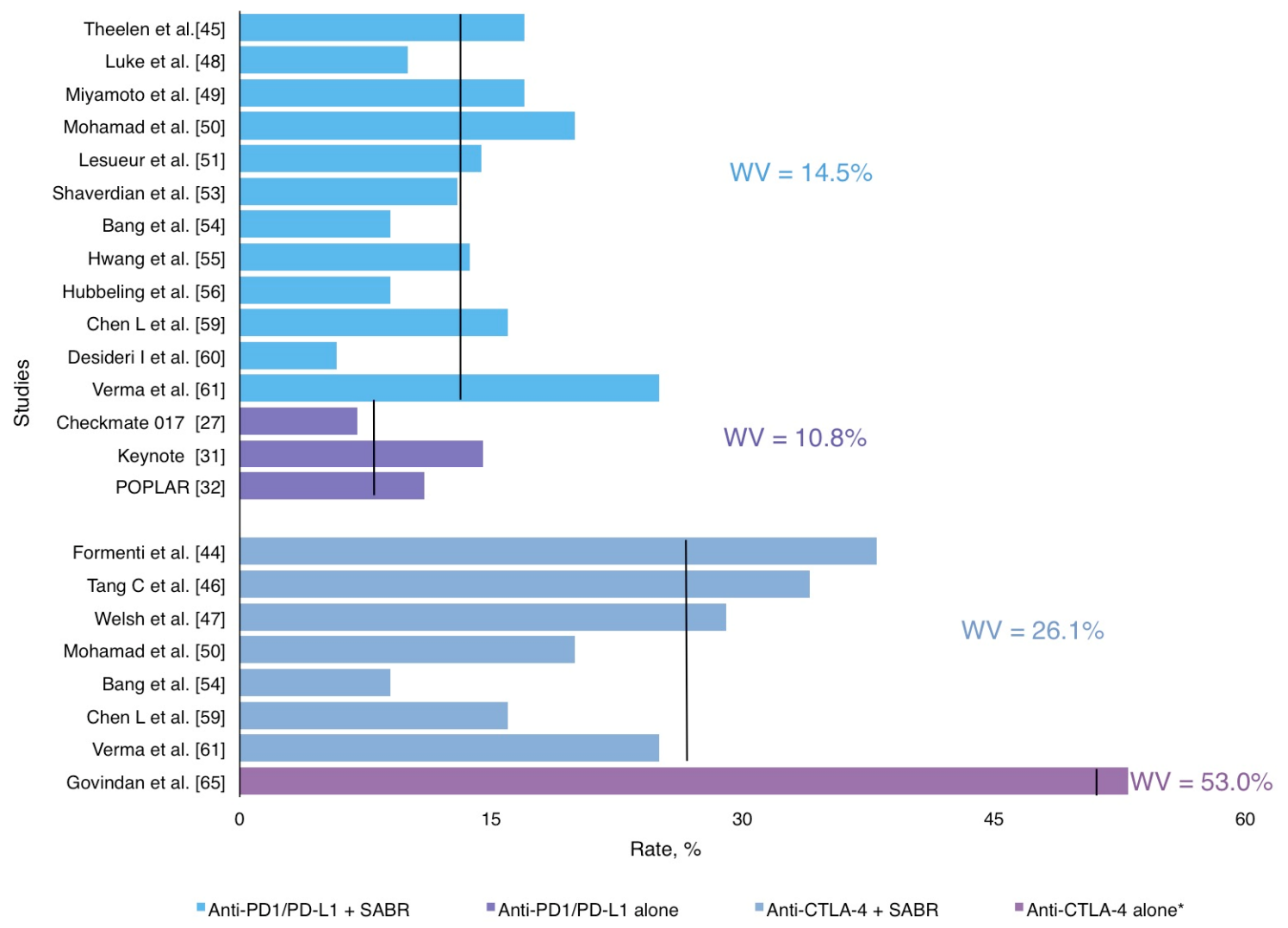

Figure 5. Grade $\geq 3$ Adverse Events in SABR and ICI combination treatment.

Still, out of the 6 prospective studies, the phase II trial by Theleen et al. [45] did include a control arm of ICI alone. This study compared the use of pembrolizumab with or without radiotherapy in NSCLC. Their results showed grade $\geq 3$ toxicity of $22 \%$ in the pembrolizumab arm versus $17 \%$ in the pembrolizumab plus radiotherapy arm. Furthermore, the PACIFIC III trial showed comparable grade $\geq 3$ toxicity between the ICI and control groups, even though this study did not include metastatic patients, but did include patients with locally advanced stage 3 NSCLC [67].

Therefore, the combination of radiotherapy and immunotherapy seems to be safe. However, some studies do report increased grade $\geq 3$ toxicity. In particular, three trials testing the combination of ipilimumab with radiotherapy presented 34\% (Tang et al.), 29\% (Welsh et al.) and 38\% (Formenti et al.) grade $\geq 3$ toxicities $[44,46,47]$. It must be noted that the first study did not specify which toxicities were attributable to the combined treatment, while the second and third trial showed that only $2 \%$ and $10 \%$ respectively were caused by the combination of ICI and RT. Furthermore, these studies include patients treated with chemotherapy in addition to ICI.

As stated before, evidence of AEs from prospective trials is still limited. However, there are a growing number of retrospective studies that may provide useful data. Grade $\geq 3$ toxicities in these studies range from $5.8 \%$ to $25 \%$, which is consistent with historical controls and further supports the idea that the combination of ICI and radiotherapy is safe (Figure 5). Again, a number of patients 
also received treatment with chemotherapy, which can explain the increased rate of AEs in some of these studies.

Although the available evidence suggests that RT does not increase the side effect profile of immunotherapy, there are still many questions regarding if different treatment-related variables can have an influence on the severity of these toxicities.

One increasingly important subject involves treatment timing and sequencing. In the prospective clinical trials that we reviewed, radiotherapy was administered either concurrently or within seven days of the first dose of ICI, with the exception of Miyamoto et al. [49], where treatment with nivolumab started within two weeks of the first fraction of SBRT. Moreover, patients in the PACIFIC trial were randomized 1-42 days after chemo-radiotherapy. In the trial by Tang et al. [46], patients receiving a sequential treatment presented grade $\geq 3$ toxicity of $25 \%-50 \%$ in comparison to $29 \%-33 \%$ in the concurrent treatment group. However, in this study only 8 of the 35 patients had lung cancer and the toxicity of this specific group was not described. The rest of the prospective studies do not report differences in toxicity.

Regarding the retrospective studies, most of them do not analyze specific differences in toxicity according to timing. In the ones that delivered both concurrent and sequential treatments, all but one study found no significant differences in toxicity. The study by Bang et al. [54] did describe a trend towards higher overall toxicity when radiation was administered within 14 days of immunotherapy ( $39 \%$ vs $23 \%, p=0.06)$. However, no significant differences in grade $\geq 3$ AEs were observed.

Further prospective studies are needed to determine if the sequence or interval between treatments might have an impact on toxicity.

A fundamental matter regarding AEs has to do with follow-up in the long term. Immune-induced side effects can appear months after treatment, while toxicity from RT may emerge even years later. At the moment, given that the prospective trials available are very recent, follow-up is still very short. The exception is the study by Formenti et al. [44], which has a median follow-up of 43 months. As for retrospective studies, follow-up ranges between 6-32 months. For this reason, further studies are needed in order to verify that toxicity profiles do not increase over time.

In regard to other variables such as RT fractionation or treatment site, there is not enough data available to draw conclusions on how they might affect toxicity profiles. Specific differences in toxicity between radiotherapy schedules were not analyzed in any of the studies. Authors like Bang et al. [54] describe a relation between overall toxicity and BED. However, grade $\geq 3$ AEs do not seem to increase with high BED.

Furthermore, most of the studies do not specify toxicity rates by treatment site. Bang et al. [54] found no significant link between site-specific immune toxicity and radiation administered in the corresponding anatomical area. In any case, future prospective trials should shed some light on these matters.

As a whole, the combination of ICI and radiotherapy seems to be comparable with ICI monotherapy in terms of toxicity. However, it must be noted that the available data is still preliminary and most of this data does not come from prospective trials. Moreover, evidence on how treatment variables might affect toxicity profiles is lacking, although the results from the present studies generally have not found significant differences. Future prospective studies are needed to confirm these findings.

\subsection{Futures Perspectives}

Immunotherapy has represented a paradigm shift in the treatment of NSCLC. Due to its positive results in recent studies, there is a trend towards treating a growing number of patients with ICI. For this reason, finding out which patients will benefit the most from these treatments is becoming essential. The addition of other therapies to ICI seems to be a good way of getting closer to an optimal treatment. As it has been stated in this review, RT in particular is a very promising approach, and novel ways of delivering these treatments are constantly in the works. For instance, a recent review described how nanoparticles have the potential to enhance abscopal responses in an RT-ICI combination [68]. 
All these new approaches, along with future prospective trials, will help determine the best way of administering what is shaping up to be a very promising therapy.

\section{Conclusions}

Even though several studies showed an increase in median OS and PFS, a pooled analysis of these studies does not indicate a general increase in median OS and PFS, observing similar results to the ICI alone baseline studies described in this article. On the other hand, a consistent outcome among all studies is an increased distant/abscopal response rate in patients treated with SABR and ICI, suggesting the potential of radiotherapy to turn traditional non-responders into responders. Why these clear clinical outcomes advantages do not translate into OS and PFS would be explained, for the heavily pretreatment that precludes further systemic treatment after progression to ICI+RT. With the current scientific evidence provided, this treatment combination looks like a promising therapeutic approach, and further prospective studies could shed some light on the ideal treatment schedule involving ICI association and optimal RT timing, dosage and fractionation.

Funding: This research received no external funding.

Conflicts of Interest: The authors declare no conflict of interest.

\section{References}

1. Siegel, R.L.; Miller, K.D.; Jemal, A. Cancer statistics. CA Cancer J. Clin. 2016, 66, 7-30. [CrossRef] [PubMed]

2. Howlader, N.; Noone, A.M.; Krapcho, M.; Neyman, N.; Aminou, R.; Waldron, W.; Altekruse, S.F.; Kosary, C.L.; Ruhl, J.; Tatalovich, Z.; et al. (Eds.) SEER Cancer Statistics Review, 1975-2008; National Cancer Institute: Bethesda, MD, USA, 2010.

3. Goldstraw, P.; Chansky, K.; Crowley, J.; Rami-Porta, R.; Asamura, H.; Eberhardt, W.E.; Nicholson, A.G.; Groome, P.; Mitchell, A.; Bolejack, V. The IASLC lung cancer staging project: Proposals for revision of the TNM stage groupings in the forthcoming (eighth) edition of the TNM Classification for lung cancer. J. Thorac. Oncol. 2016, 11, 39-51. [CrossRef]

4. National Comprehensive Cancer Network. NCCN Clinical Practice Guidelines in Oncology (NCCN Guidelines): Non-Small Cell Lung Cancer Version 3 2019. Available online: https://www.nccn.org/ professionals/physician_gls/pdf/nscl.pdf (accessed on 18 January 2019).

5. Videtic, G.M.; Donington, J.; Giuliani, M.; Heinzerling, J.; Karas, T.Z.; Kelsey, C.R.; Lally, B.E.; Latzka, K.; Lo, S.S.; Moghanaki, D.; et al. Stereotactic body radiation therapy for early-stage non-small cell lung cancer: Executive Summary of an ASTRO Evidence-Based Guideline. Pr. Radiat. Oncol. 2017, 7, 295-301. [CrossRef] [PubMed]

6. Uematsu, M.; Shioda, A.; Tahara, K.; Fukui, T.; Yamamoto, F.; Tsumatori, G.; Ozeki, Y.; Aoki, T.; Watanabe, M.; Kusano, S. Focal, high dose, and fractionated modified stereotactic radiation therapy for lung carcinoma patients: a preliminary experience. Cancer 1998, 82, 1062-1070. [CrossRef]

7. Baumann, P.; Nyman, J.; Hoyer, M.; Wennberg, B.; Gagliardi, G.; Lax, I.; Drugge, N.; Ekberg, L.; Friesland, S.; Johansson, K.-A.; et al. Outcome in a Prospective Phase II Trial of Medically Inoperable Stage I Non-Small-Cell Lung Cancer Patients Treated With Stereotactic Body Radiotherapy. J. Clin. Oncol. 2009, 27, 3290-3296. [CrossRef] [PubMed]

8. McGarry, R.C.; Papiez, L.; Williams, M.; Whitford, T.; Timmerman, R.D. Stereotactic body radiation therapy of early-stage non-small-cell lung carcinoma: Phase I study. Int. J. Radiat. Oncol. 2005, 63, 1010-1015. [CrossRef]

9. Fakiris, A.J.; McGarry, R.C.; Yiannoutsos, C.T.; Papiez, L.; Williams, M.; Henderson, M.A.; Timmerman, R. Stereotactic Body Radiation Therapy for Early-Stage Non-Small-Cell Lung Carcinoma: Four-Year Results of a Prospective Phase II Study. Int. J. Radiat. Oncol. 2009, 75, 677-682. [CrossRef] [PubMed]

10. Timmerman, R.; Paulus, R.; Galvin, J.; Michalski, J.; Straube, W.; Bradley, J.; Fakiris, A.; Bezjak, A.; Videtic, G.; Johnstone, D.; et al. Stereotactic Body Radiation Therapy for Inoperable Early Stage Lung Cancer. JAMA 2010, 303, 1070-1076. [CrossRef] 
11. Iyengar, P.; Wardak, Z.; Gerber, D.E.; Tumati, V.; Ahn, C.; Hughes, R.S.; Dowell, J.E.; Cheedella, N.; Nedzi, L.; Westover, K.D.; et al. Consolidative Radiotherapy for Limited Metastatic Non-Small-Cell Lung Cancer: A Phase 2 Randomized Clinical Trial. JAMA Oncol. 2018, 4, e173501. [CrossRef]

12. Palma, D.A.; Haasbeek, C.J.; Rodrigues, G.B.; Dahele, M.; Lock, M.; Yaremko, B.; Olson, R.; Liu, M.; Panarotto, J.; Griffioen, G.H.; et al. Stereotactic ablative radiotherapy for comprehensive treatment of oligometastatic tumors (SABR-COMET): study protocol for a randomized phase II trial. BMC Cancer 2012, 12, 305. [CrossRef]

13. Iyengar, P.; Kavanagh, B.D.; Wardak, Z.; Smith, I.; Ahn, C.; Gerber, D.E.; Dowell, J.; Hughes, R.; Abdulrahman, R.; Camidge, D.R.; et al. Phase II Trial of Stereotactic Body Radiation Therapy Combined With Erlotinib for Patients With Limited but Progressive Metastatic Non-Small-Cell Lung Cancer. J. Clin. Oncol. 2014, 32, 3824-3830. [CrossRef] [PubMed]

14. Collen, C.; Christian, N.; Schallier, D.; Meysman, M.; Duchateau, M.; Storme, G.; De Ridder, M. Phase II study of stereotactic body radiotherapy to primary tumor and metastatic locations in oligometastatic nonsmall-cell lung cancer patients. Ann. Oncol. 2014, 25, 1954-1959. [CrossRef] [PubMed]

15. De Ruysscher, D.; Wanders, R.; van Baardwijk, A.; Dingemans, A.M.; Reymen, B.; Houben, R.; Bootsma, G.; Pitz, C.; van Eijsden, L.; Geraedts, W.; et al. Radical treatment of non-small-cell lung cancer patients with synchronous oligometastases: long-term results of a prospective phase II trial (Nct01282450). J. Thorac. Oncol. 2012, 7, 1547-1555. [CrossRef] [PubMed]

16. Downey, R.J.; Ng, K.K.; Kris, M.G.; Bains, M.S.; A Miller, V.; Heelan, R.; Bilsky, M.; Ginsberg, R.; Rusch, V.W. A phase II trial of chemotherapy and surgery for non-small cell lung cancer patients with a synchronous solitary metastasis. Lung Cancer 2002, 38, 193-197. [CrossRef]

17. de Vin, T.; Engels, B.; Gevaert, T.; Storme, G.; De Ridder, M. Stereotactic radiotherapy for oligometastatic cancer: a prognostic model for survival. Ann. Oncol. 2014, 25, 467-471. [CrossRef]

18. Hasselle, M.D.; Haraf, D.J.; Rusthoven, K.E.; Golden, D.W.; Salgia, R.; Villaflor, V.M.; Shah, N.; Hoffman, P.C.; Chmura, S.J.; Connell, P.P.; et al. Hypofractionated Image-Guided Radiation Therapy for Patients with Limited Volume Metastatic Non-small Cell Lung Cancer. J. Thorac. Oncol. 2012, 7, 376-381. [CrossRef]

19. Khan, A.J.; Mehta, P.S.; Zusag, T.W.; Bonomi, P.D.; Faber, L.P.; Shott, S.; Abrams, R.A. Long term disease-free survival resulting from combined modality management of patients presenting with oligometastatic, non-small cell lung carcinoma (NSCLC). Radiother. Oncol. 2006, 81, 163-167. [CrossRef] [PubMed]

20. Li, D.; Zhu, X.; Wang, H.; Qiu, M.; Li, N. Should aggressive thoracic therapy be performed in patients with synchronous oligometastatic non-small cell lung cancer? A meta-analysis. J. Thorac. 2017, 9, $310-317$. [CrossRef]

21. Su, S.; Hu, Y.; Ouyang, W.; Ma, Z.; Li, Q.; Li, H.; Wang, Y.; Wang, X.; Li, T.; Li, J.; et al. Might radiation therapy in addition to chemotherapy improve overall survival of patients with non-oligometastatic Stage IV non-small cell lung cancer?: Secondary analysis of two prospective studies. BMC Cancer 2016, 16, 5. [CrossRef]

22. Lopez Guerra, J.L.; Gomez, D.; Zhuang, Y.; Hong, D.; Heymach, J.; Swisher, S.; Lin, S.; Komaki, R.; Cox, J.; Liao, Z. Prognostic impact of radiation therapy to the primary tumor in patients with non-small cell lung cancer and oligometastasis at diagnosis. Int. J. Radiat. Oncol. Biol. Phys. 2012, 84, e61-e67. [CrossRef]

23. Sheu, T.; Heymach, J.V.; Swisher, S.G.; Rao, G.; Weinberg, J.S.; Mehran, R.; McAleer, M.F.; Liao, Z.; Aloia, T.A.; Gomez, D.R. Propensity Score-Matched Analysis of Comprehensive Local Therapy for Oligometastatic Non-Small Cell Lung Cancer That Did Not Progress After Front-Line Chemotherapy. Int. J. Radiat. Oncol. 2014, 90, 850-857. [CrossRef]

24. Gomez, D.R.; Blumenschein, G.R.; Lee, J.J.; Hernandez, M.; Ye, R.; Camidge, D.R.; Doebele, R.C.; Skoulidis, F.; Gaspar, L.E.; Gibbons, D.L.; et al. Local consolidative therapy versus maintenance therapy or observation for patients with oligometastatic non-small-cell lung cancer without progression after first-line systemic therapy: a multicenter, randomized, controlled, phase 2 study. Lancet Oncol. 2016, 17, 1672-1682. [CrossRef]

25. Topalian, S.L.; Hodi, F.S.; Brahmer, J.R.; Gettinger, S.N.; Smith, D.C.; McDermott, D.F.; Powderly, J.D.; Carvajal, R.D.; Sosman, J.A.; Atkins, M.B.; et al. Safety, Activity, and Immune Correlates of Anti-PD-1 Antibody in Cancer. N. Engl. J. Med. 2012, 366, 2443-2454. [CrossRef]

26. Prado-Garcia, H.; Romero-Garcia, S.; Aguilar-Cazares, D.; Meneses-Flores, M.; Lopez-Gonzalez, J.S. Tumor-induced CD81T-cell dysfunction in lung cancer patients. Clin. Dev. Immunol. 2012, 2012, 741741. [CrossRef] [PubMed] 
27. Brahmer, J.; Reckamp, K.L.; Baas, P.; Crinò, L.; Eberhardt, W.; Poddubskaya, E.; Antonia, S.; Pluzanski, A.; Vokes, E.; Holgado, E.; et al. Nivolumab versus docetaxel in advanced squamous-cell nonsmall-cell lung cancer. N. Engl. J. Med. 2015, 373, 123-135. [CrossRef] [PubMed]

28. Borghaei, H.; Paz-Ares, L.; Horn, L.; Spigel, D.; Steins, M.; Ready, N.; Chow, L.; Vokes, E.; Felip, E.; Holgado, E.; et al. Nivolumab versus docetaxel in advanced nonsquamous non-small-cell lung cancer. N. Engl. J. Med. 2015, 373, 1627-1639. [CrossRef] [PubMed]

29. Postow, M.A.; Callahan, M.K.; Wolchok, J.D. Immune Checkpoint Blockade in Cancer Therapy. J. Clin. Oncol. 2015, 33, 1974-1982. [CrossRef] [PubMed]

30. Carbone, D.P.; Reck, M.; Paz-Ares, L.; Creelan, B.; Horn, L.; Steins, M.; Felip, E.; Heuvel, M.M.V.D.; Ciuleanu, T.-E.; Badin, F.; et al. First-Line Nivolumab in Stage IV or Recurrent Non-Small-Cell Lung Cancer. N. Engl. J. Med. 2017, 376, 2415-2426. [CrossRef]

31. Herbst, R.S.; Baas, P.; Kim, D.-W.; Felip, E.; Perez-Gracia, J.L.; Han, J.-Y.; Molina, J.; Kim, J.-H.; Arvis, C.D.; Ahn, M.-J.; et al. Pembrolizumab versus docetaxel for previously treated, PD-L1-positive, advanced non-small-cell lung cancer (KEYNOTE-010): a randomised controlled trial. Lancet 2016, 387, 1540-1550. [CrossRef]

32. Fehrenbacher, L.; Spira, A.; Ballinger, M.; Kowanetz, M.; Vansteenkiste, J.; Mazieres, J.; Park, K.; Smith, D.; Artal-Cortes, A.; Lewanski, C.; et al. Atezolizumab versus docetaxel for patients with previously treated non-small-cell lung cancer (POPLAR): A multicentre, open-label, phase 2 randomised controlled trial. Lancet 2016, 387, 1837-1846. [CrossRef]

33. Zatloukal, P.; Heo, D.; Park, K.; Kang, J.; Butts, C.; Bradford, D.; Graziano, S.; Huang, B.; Healey, D. Randomized phase II clinical trial comparing tremelimumab (CP- 675,206) with best supportive care (BSC) following first-line platinum-based therapy in patients (pts) with advanced non-small cell lung cancer (NSCLC). J. Clin. Oncol. 2009, 27, 8071a.

34. Lynch, T.J.; Bondarenko, I.; Luft, A.; Kang, J.; Butts, C.; Bradford, D.; Graziano, S.; Huang, B.; Healey, D.; et al. Ipilimumab in combination with paclitaxel and carboplatin as first-line treatment in stage IIIB/IV non-small-cell lung cancer: Results from a randomized, double blind, multicenter phase II study. J. Clin. Oncol. 2012, 30, 2046-2054. [CrossRef]

35. Carretero-González, A.; Lora, D.; Ghanem, I.; Zugazagoitia, J.; Castellano, D.; Sepulveda, J.M.; López-Martín, J.A.; Paz-Ares, L.; De Velasco, G. Analysis of response rate with ANTI PD1/PD-L1 monoclonal antibodies in advanced solid tumors: a meta-analysis of randomized clinical trials. Oncotarget 2018, 9, 8706-8715. [CrossRef] [PubMed]

36. Galluzzi, L.; Buque, A.; Kepp, O.; Zitvogel, L.; Kroemer, G. Immunogenic cell death in cancer and infectious disease. Nat. Rev. Immunol. 2017, 17, 97-111. [CrossRef]

37. Rodríguez-Ruiz, M.E.; Vanpouille-Box, C.; Melero, I.; Formenti, S.C.; DeMaria, S. Immunological Mechanisms Responsible for Radiation-Induced Abscopal Effect. Trends Immunol. 2018, 39, 644-655. [CrossRef] [PubMed]

38. Deng, L.; Liang, H.; Burnette, B.; Beckett, M.; Darga, T.; Weichselbaum, R.R.; Fu, Y.-X. Irradiation and anti-PD-L1 treatment synergistically promote antitumor immunity in mice. J. Clin. Investig. 2014, 124, 687-695. [CrossRef] [PubMed]

39. Lara, P.C.; Lopez-Penalver, J.J.; Farias Vde, A.; Ruiz-Ruiz, M.C.; Oliver, F.J.; Ruiz de Amodovar, J.M. Direct and bystander radiation effects: a biophysical model and clinical perpectives. Cancer Lett. 2015, 356, 5-16. [CrossRef] [PubMed]

40. Sologuren, I.; Rodriguez-Gallego, C.; Lara, P.C. Immune effects of high dose radiation treatment: Implications of ionizing radiation on the development of bystander and abscopal effects. Transl. Cancer Res. 2014, 3, 18-31.

41. Mole, R.J. Whole body irradiation - Radiology or medicine? Br. J. Radiol. 1953, 26, 234-241. [CrossRef] [PubMed]

42. Chicas-Sett, R.; Morales-Orue, I.; Rodriguez-Abreu, D.; Lara-Jimenez, P. Combining radiotherapy and ipilimumab induces clinically relevant radiation-induced abscopal effects in metastatic melanoma patients: A systematic review. Clin. Transl. Radiat. Oncol. 2018, 9, 5-11. [CrossRef]

43. Freedman, D.; Pisani, R.; Purves, R. Statistics, 3rd ed.; WW Norton \& Company: New York, NY, USA, 1998. 
44. Formenti, S.C.; Rudqvist, N.-P.; Golden, E.; Cooper, B.; Wennerberg, E.; Lhuillier, C.; Vanpouille-Box, C.; Friedman, K.; De Andrade, L.F.; Wucherpfennig, K.W.; et al. Radiotherapy induces responses of lung cancer to CTLA-4 blockade. Nat. Med. 2018, 24, 1845-1851. [CrossRef] [PubMed]

45. Theelen, W.; Lalezari, F.; De Vries, J.; De Langen, J.; Aerts, J.; Monkhorst, K.; Baas, P. Randomized phase II study of pembrolizumab after stereotactic body radiotherapy (SBRT) versus pembrolizumab alone in patients with advanced non-small cell lung cancer: The PEMBRO-RT study. J. Clin. Oncol. 2018, 36, 9023. [CrossRef]

46. Tang, C.; Welsh, J.W.; de Groot, P.; Massarelli, E.; Chang, J.Y.; Hess, K.R.; Basu, S.; Curran, M.A.; Cabanillas, M.E.; Subbiah, V.; et al. Ipilimumab with stereotactic ablative radiation therapy: Phase I results and immunologic correlates from peripheral T cells. Clin. Cancer Res. 2017, 23, 1388-1396. [CrossRef] [PubMed]

47. Welsh, J.W.; Tang, C.; de Groot, P.; Naing, A.; Raju, U.; Shaaban, S.; Chang, J.Y.; Cushman, T.; Heymach, J.; Dadu, R.; et al. Phase II 5-arm trial of ipilimumab plus lung or liver stereotactic radiation for patients with advanced malignancies. Int. J. Radiat. Oncol. Biol. Phys. 2017, 99, 1315. [CrossRef]

48. Luke, J.J.; Lemons, J.M.; Karrison, T.G.; Pitroda, S.P.; Melotek, J.M.; Zha, Y.; Al-Hallaq, H.A.; Arina, A.; Khodarev, N.N.; Janisc, L.; et al. Safety and clinical activity of pembrolizumab and multisite stereotactic body radiotherapy in patients with advanced solid tumors. J. Clin. Oncol. 2018, 36, 1611-1618. [CrossRef] [PubMed]

49. Miyamoto, S.; Nomura, R.; Sato, K.; Awano, N.; Kuse, N.; Inomata, M.; Izumo, T.; Terada, Y.; Furuhata, Y.; Bae, Y.; et al. Nivolumab and stereotactic radiation therapy for the treatment of patients with Stage IV non-small-cell lung cancer. Jpn. J. Clin. Oncol. 2019, 49, 160-164. [CrossRef]

50. Mohamad, O.; De Leon, A.D.; Schroeder, S.; Leiker, A.; Christie, A.; Zhang-Velten, E.; Trivedi, L.; Khan, S.; Desai, N.B.; Laine, A.; et al. Safety and efficacy of concurrent immune checkpoint inhibitors and hypofractionated body radiotherapy. OncoImmunology 2018, 7, e1440168. [CrossRef]

51. Lesueur, P.; Escande, A.; Thariat, J.; Vauléon, E.; Monnet, I.; Cortot, A.; Lerouge, D.; Danhier, S.; Dô, P.; Dubos-Arvis, C.; et al. Safety of combined PD-1 pathway inhibition and radiation therapy for non-small-cell lung cancer: A multicentric retrospective study from the GFPC. Cancer Med. 2018, 7, 5505-5513. [CrossRef]

52. Foster, C.C.; Sher, D.J.; Rusthoven, C.G.; Verma, V.; Spiotto, M.T.; Weichselbaum, R.R.; Koshy, M. Overall survival according to immunotherapy and radiation treatment for metastatic non-small-cell lung cancer: A National Cancer Database analysis. Radiat. Oncol. 2019, 14, 18. [CrossRef]

53. Shaverdian, N.; E Lisberg, A.; Bornazyan, K.; Veruttipong, D.; Goldman, J.W.; Formenti, S.C.; Garon, E.B.; Lee, P. Previous radiotherapy and the clinical activity and toxicity of pembrolizumab in the treatment of non-small-cell lung cancer: a secondary analysis of the KEYNOTE-001 phase 1 trial. Lancet Oncol. 2017, 18, 895-903. [CrossRef]

54. Bang, A.; Wilhite, T.J.; Pike, L.R.G.; Cagney, D.N.; Aizer, A.A.; Taylor, A.; Spektor, A.; Krishnan, M.; Ott, P.A.; Balboni, T.A.; et al. Multicenter evaluation of the tolerability of combined treatment with PD-1 and CTLA-4 immune ckeckpoint inhibitors and palliative radiation therapy. Int. J. Radiat. Oncol. Biol. Phys. 2017, 98, 344-351. [CrossRef] [PubMed]

55. Hwang, W.L.; Niemierko, A.; Hwang, K.L.; Hubbeling, H.; Schapira, E.; Gainor, J.F.; Keane, F.K. Clinical outcomes in patients with metastatic lung cancer treated with PD-1/PD-L1 inhibitors and thoracic radiotherapy. JAMA Oncol. 2018, 4, 253-255. [CrossRef]

56. Hubbeling, H.G.; Schapira, E.F.; Horick, N.K.; Goodwin, K.E.; Lin, J.J.; Oh, K.S.; Shaw, A.T.; Mehan, W.A.; Shih, H.A.; Gainor, J.F. Safety of Combined PD-1 Pathway Inhibition and Intracranial Radiation Therapy in Non-Small Cell Lung Cancer. J. Thorac. Oncol. 2018, 13, 550-558. [CrossRef]

57. Martin, A.M.; Cagney, D.N.; Catalano, P.J.; Alexander, B.M.; Redig, A.J.; Schoenfeld, J.D.; Aizer, A.A. Immunotherapy and Symptomatic Radiation Necrosis in Patients With Brain Metastases Treated With Stereotactic Radiation. JAMA Oncol. 2018, 4, 1123-1124. [CrossRef]

58. Colaco, R.J.; Martin, P.; Kluger, H.M.; Yu, J.B.; Chiang, V.L. Does immunotherapy increase the rate of radiation necrosis after radiosurgery treatment of brain metastases? J. Neurosurg. 2016, 125, 17-23. [CrossRef] [PubMed]

59. Chen, L.; Douglass, J.; Kleinberg, L.; Ye, X.; Marciscano, A.E.; Forde, P.M.; Brahmer, J.; Lipson, E.; Sharfman, W.; Hammers, H.; et al. oncurrent immune checkpoint inhibitors and stereotactic radiosurgery for brain 
metastases in non-small cell lung cancer, melanoma, and renal cell carcinoma. Int. J. Radiat. Oncol. Biol. Phys. 2018, 100, 916-925. [CrossRef] [PubMed]

60. Desideri, I.; Francolini, G.; Scotti, V.; Pezzulla, D.; Becherini, C.; Terziani, F.; Paoli, C.D.; Olmetto, E.; Visani, L.; Meattini, I.; et al. Benefit of ablative versus palliative-only radiotherapy in combination with nivolumab in patients affected by metastatic kidney and lung cancer. Clin. Transl. Oncol. 2018. [CrossRef]

61. Verma, V.; Cushman, T.R.; Selek, U.; Tang, C.; Welsh, J.W. Safety of Combined Immunotherapy and Thoracic Radiation Therapy: Analysis of 3 Single-Institutional Phase I/II Trials. Int. J. Radiat. Oncol. 2018, 101, 1141-1148. [CrossRef] [PubMed]

62. Timmerman, R.D.; Paulus, R.; I Pass, H.; Gore, E.M.; Edelman, M.J.; Galvin, J.; Straube, W.L.; A Nedzi, L.; McGarry, R.C.; Robinson, C.G.; et al. Stereotactic Body Radiation Therapy for Operable Early-Stage Lung Cancer: Findings From the NRG Oncology RTOG 0618 Trial. JAMA Oncol. 2018, 4, 1263-1266. [CrossRef]

63. Marciscano, A.E.; Haimovitz-Friedman, A.; Lee, P.; Tran, P.T.; Tomé, W.A.; Guha, C.; Kong, F.-M.; Sahgal, A.; El Naqa, I.; Rimner, A.; et al. Immunomodulatory Effects of Stereotactic Body Radiation Therapy: Preclinical Insights and Clinical Opportunities. Int. J. Radiat. Oncol. 2019. [CrossRef]

64. Gide, T.N.; Wilmott, J.S.; Scoyler, R.A.; Long, V.G. Primary and acquired resistance to immune checkpoint inhibitors in metastatic melanoma. Clin. Cancer Res. 2018, 24, 1260-1270. [CrossRef]

65. Pike, L.R.G.; Bang, A.; Ott, P.; Balbonic, T.; Taylor, A.; Catalano, P.; Rawal, B.; Spektor, A.; Krishnan, M.; Cagney, D.; et al. Radiation and PD-1 inhibition: favorable outcomes after brain-directed radiation. Radiother. Oncol. 2017, 124, 98-103. [CrossRef]

66. Govindan, R.; Szczesna, A.; Ahn, M.-J.; Schneider, C.-P.; Mella, P.F.G.; Barlesi, F.; Han, B.; Ganea, D.E.; Von Pawel, J.; Vladimirov, V.; et al. Phase III Trial of Ipilimumab Combined With Paclitaxel and Carboplatin in Advanced Squamous Non-Small-Cell Lung Cancer. J. Clin. Oncol. 2017, 35, 3449-3457. [CrossRef] [PubMed]

67. Antonia, S.J.; Villegas, A.; Daniel, D.; Vicente, D.; Murakami, S.; Hui, R.; Yokoi, T.; Chiappori, A.; Lee, K.H.; de Wit, M.; et al. Durvalumab after chemotherapy in stage III non-small-cell lung cancer. N. Engl. J. Med. 2017, 377, 1919-1929. [CrossRef] [PubMed]

68. Morales-Orue, I.; Chicas-Sett, R.; Lara, P.C. Nanoparticles as a promising method to enhance the abscopal effect in the era of new targeted therapies. Rep. Pr. Oncol. Radiother. 2019, 24, 86-91. [CrossRef] [PubMed]

(C) 2019 by the authors. Licensee MDPI, Basel, Switzerland. This article is an open access article distributed under the terms and conditions of the Creative Commons Attribution (CC BY) license (http://creativecommons.org/licenses/by/4.0/). 